\section{Fernanda Majolo}

PhD, Pontifícia Universidade Católica do Rio Grande do Sul, PUC-RS Porto Alegre (RS), Brazil.

\section{Claudete Rempel}

Doutora, Universidade do Vale do Taquari, Univates - Lajeado (RS), Brazil.

\section{Corresponding address:}

Fernanda Majolo - Programa de Pós-Graduação em Medicina e Ciências da Saúde, Pontifícia Universidade Católica do Rio Grande do Sul - Avenida Ipiranga, 6681 - Partenon - CEP 90610-000Porto Alegre (RS), Brasil. E-mail: fernanda.majolo@acad.pucrs.br

Received on: 07/10/2018

Accepted on: $12 / 05 / 2018$

\begin{abstract}
Brazil is the third largest market and the eighth largest consumer of pesticides per hectare in the world, with herbicides and insecticides accounting for $60 \%$ of the products traded in the country. The use of pesticides has increased worldwide in the last decades, which may represent a risk for several diseases in humans, including cancer. Although in Brazil the research on the impact of the use of pesticides on human health has grown in recent years, it is still insufficient to really know the real dimension of health damage caused mainly by occupational and food exposure, due to the intensive use of pesticides. This article aims to review the use of pesticides by rural workers in Brazil, highlighting the importance of preventive measures for their health.
\end{abstract}

Keywords: health disorders; occupational health; cancer; genotoxicity; oxidative stress; strategies.

\section{RESUMO}

OBrasilé o terceiro maior mercado e o oitavo maior consumidor de agrotóxicos por hectare do mundo, com herbicidas e inseticidas correspondendo a $60 \%$ dos produtos comercializados no país. $O$ uso de agrotóxicos tem aumentado em todo o mundo nas últimas décadas, o que pode representar um risco para diversas doenças em humanos, incluindo o câncer. Embora, no Brasil, a pesquisa sobre o impacto do uso de agrotóxicos na saúde humana tenha crescido nos últimos anos, ainda é insuficiente para de fato conhecer a real dimensão dos danos à saúde, causados principalmente pela exposição ocupacional e alimentar, em virtude da utilização de agrotóxicos. Esta revisão tem por objetivo destacar o uso de pesticidas por trabalhadores rurais no Brasil, evidenciando a importância de medidas preventivas para a saúde do trabalhador.

Palavras-chave: transtornos de saúde; saúde ocupacional; câncer; genotoxicidade; estresse oxidativo; estratégias. 


\section{INTRODUCTION}

Pesticides, according to the World Health Organization (WHO, 2008), is any substance capable of controlling a pest that can have consequences for both the population and the environment. Among the countries with agricultural power involving the consumption of herbicides, fungicides and agricultural insecticides, Brazil ranks first in the Latin American and Caribbean Newsletter, dated 23 of April 2011 (STÉDILE, 2012; NEVES, 2017).

In Brazil, the diversity of agrochemicals is big, about 300 active principles in more than 2 thousand commercial formulations (NEVES, 2017). Humans are often their final recipients, and they can be found in the soil, water, air, in animals and vegetables, being thus considered with great capacity of dispersion (NEVES, 2017). Different symptoms are caused by pesticide poisoning, mainly among farmers, and may even make them stop working and having to look for another type of profession. Among the symptoms, we can highlight anemia, headache, dysthymia, decreased immune defenses, sexual impotence, insomnia, changes in arterial depression and behavioral disorders (LEVIGARD; ROZEMBERG, 2001; SOUZA et al., 2011).
With its effect based on insect neurotoxicity, dichlorodiphenyltrichloroethane (DDT), is a widely known pesticide, mainly because it is sold at a low cost and can act for several years (STOPELLI; MAGALHÃES, 2005). However, it has some limitations: insects have developed resistance to it and experiments with animals showed their carcinogenicity (SMITH; GANGOLLI, 2002; STOPELLI; MAGALHÃES, 2005). Already in humans, high concentrations of Dieldrin in the blood, for example, have a greater amount of thyroid stimulating hormone (TSH), presenting hypothyroidism. Therefore, this pesticide and other organochlorines act as neurotoxicants, as well as in the endocrine function (RATHORE et al., 2002; STOPELLI \& MAGALHÃES, 2005).

Many studies have presented promising results and made important conclusions beyond the use of pesticides by rural workers, allowing a better understanding of the consequences of its use. Due to the accumulated knowledge, we aimed at conducting a survey on the most important and promising researches on the use of pesticides by rural workers in Brazil until now.

\section{THE BRAZILIAN SITUATION}

Because of agricultural practices in the country, around the 1960s the whole scenario underwent modifications leading to a record consumption of agrochemicals and a chemical-dependent context of food production (ABREU; ALONZO, 2014; JACOBSON et al., 2009). In the global context, since 2008 Brazil has become the largest consumer of pesticides (CARNEIRO et al., 2012; AUGUSTO et al., 2012; RIGOTTO et al., 2012), standing out as the world's largest agricultural producer. Brazil shows growth rates of $10 \%$ per year (AGRONEWS, 2014; BRASIL, 2015; GONÇALVES, 2016) and exports food to 180 countries, being the world's leading exporter of soybeans in grains, sugar, coffee, orange juice, beef and chicken (BRASIL, 2013; GONÇALVES, 2016). According to IBAMA (2002), the states of Mato Grosso, São Paulo, Paraná, Rio Grande do Sul, Goiás, Minas Gerais, Bahia and Mato Grosso do Sul are the main consumer states of agrochemicals (Figure 1).

Especially for the rural worker, along with the evolution of techniques and the use of agricultural inputs, there have been harmful changes in health, mainly related to the loads, ways of working and risks incorporated into these new activities (STOPPELLI \& MAGALHÃES, 2005). These risks involve both acute intoxications, with the onset of symptoms fast after excessive exposure, including weakness, vomiting, nausea, seizures, muscle contractions, headaches, difficulty breathing, nasal bleeding and fainting, as well as chronic intoxication. In these, the symptoms are late after months or years, caused by small or moderate exposure to toxic products or multiple products. This type of exposure causes irreversible damage, such as paralysis and neoplasia (PERES, 1999; STOPPELLI \& MAGALHÃES, 2005), contact dermatitis, renal and hepatic lesions, delayed neurotoxic effects, chromosomal abnormalities, Parkinson's disease, cancers and teratogens (WILSON; OTSUKI, 2004; STOPPELLI \& MAGALHÃES, 2005). Table 1 shows the main studies carried out to date specifically related to the exposure of the rural worker to pesticides in Brazil. Electronic databases were collected from PUBMED and "Portal de Periódicos" from CAPES/MEC (Coordenação de Aperfeiçoamento de Pessoal de Nível Superior/ Ministério 


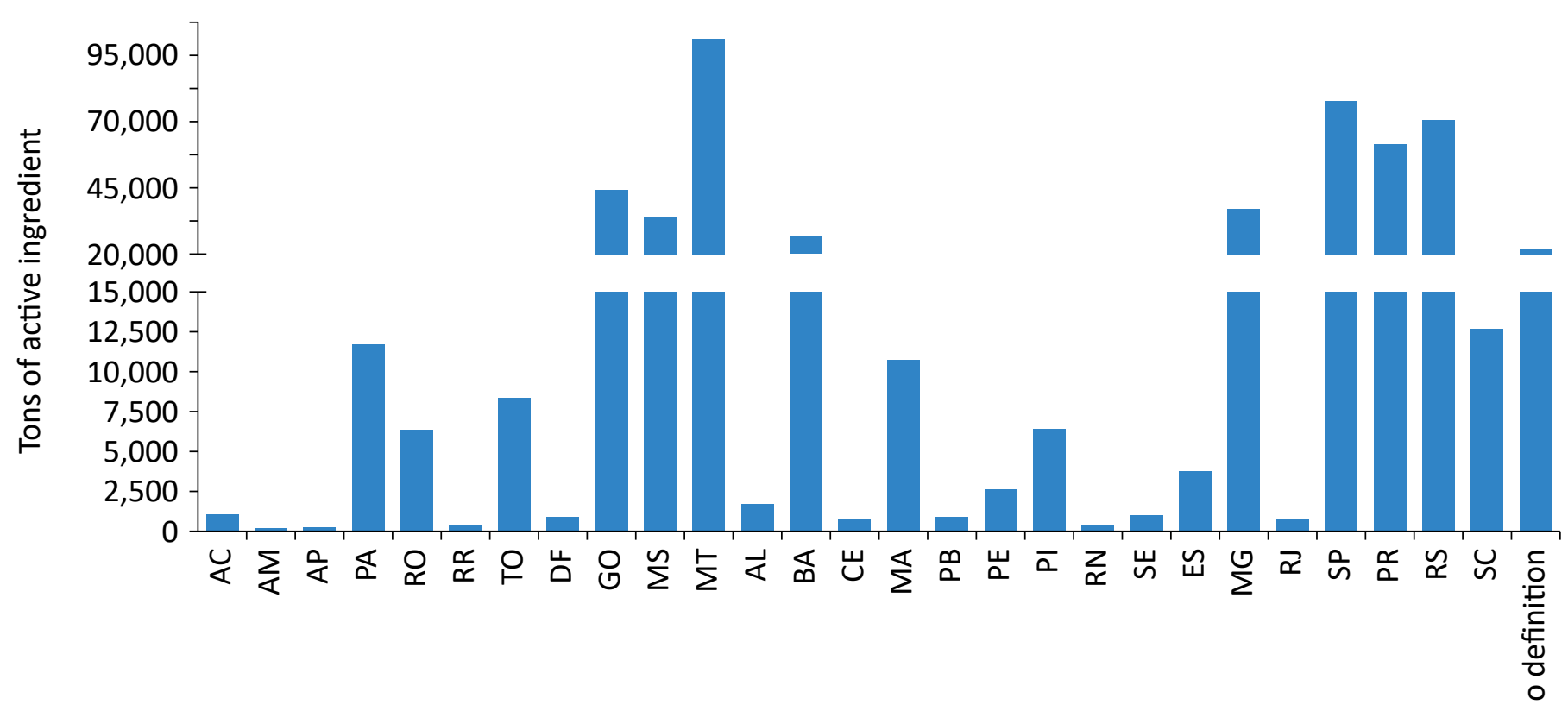

*No definition: sum of marketed quantities whose companies are not able to specify the territorial distribution of sales, since it is an activity carried out by third parties.

Figure 1 - Federation sales of agrochemicals by Unit in 2017.

Table 1 - Update of the main publications related to the use of pesticides by rural workers in Brazil.

\begin{tabular}{|c|c|c|c|c|c|}
\hline State & Target & Major findings & Methodology & Reference & Year \\
\hline \multicolumn{6}{|c|}{ HEALTH DISORDERS AND OCCUPATIONAL HEALTH } \\
\hline
\end{tabular}


Table 1 - Continuation.

\begin{tabular}{|c|c|c|c|c|c|}
\hline State & Target & Major findings & Methodology & Reference & Year \\
\hline SC & $\begin{array}{l}\text { Artificial Targets; } \\
\text { Tractor Cabins; } \\
\text { Exposure Evaluation; } \\
\text { Fenitrothion; Crop } \\
\text { Pulverization }\end{array}$ & $\begin{array}{l}\text { Sealed cabin minimized the } \\
\text { exposure of the operator to the } \\
\text { pesticides, since all samples } \\
\text { analyzed showed fenitrothion } \\
\text { values below the limit of detection. }\end{array}$ & Ultrasonic extraction & $\begin{array}{l}\text { Barcellos } \\
\text { et al. }\end{array}$ & 2016 \\
\hline RS & $\begin{array}{c}\text { Agrochemicals; Work } \\
\text { Environment; Practical } \\
\text { Nursing. }\end{array}$ & $\begin{array}{l}\text { Rural workers who apply pesticides } \\
\text { present a higher prevalence of } \\
\text { dermatological alterations. }\end{array}$ & Questionnaire & $\begin{array}{l}\text { Cezar-Vaz } \\
\text { et al. }\end{array}$ & 2016 \\
\hline RS & $\begin{array}{l}\text { Wheezing; Asthma; } \\
\text { Tobacco; Rural Health; } \\
\text { Prevalence }\end{array}$ & $\begin{array}{l}\text { Pesticides, dusts exposure, and } \\
\text { green tobacco sickness were risk } \\
\text { factors for wheezing. }\end{array}$ & Questionnaire & Fiori et al. & 2015 \\
\hline $\begin{array}{l}\text { Brazilian } \\
\text { micro- } \\
\text { region }\end{array}$ & Suicide & $\begin{array}{l}\text { Suicide rates have increased in } \\
\text { middle age (35-64 years) and } \\
\text { younger men (15-34 years). } \\
\text { Micro-regions with a higher use of } \\
\text { pesticides showed higher rates of } \\
\text { suicides. Pesticide poisoning effect } \\
\text { on suicide rates was stronger than } \\
\text { use of pesticide. Reinforces the } \\
\text { hypothesis that pesticide use and } \\
\text { pesticide poisoning increase the } \\
\text { suicide rates. }\end{array}$ & $\begin{array}{l}\text { Crude suicide } \\
\text { rates of a 15- } \\
\text { year time series } \\
(1996-2010) \text { were } \\
\text { examined, followed } \\
\text { by an ecological } \\
\text { study using } \\
\text { age-standardized } \\
\text { suicide rates for the } \\
\text { period 2006-2010. }\end{array}$ & Faria et al. & $2014 a$ \\
\hline MG & $\begin{array}{l}\text { Health and } \\
\text { Epidemiological } \\
\text { Surveillance; Health } \\
\text { Policies }\end{array}$ & $\begin{array}{l}\text { The conclusion is the pressing } \\
\text { need to develop a model for } \\
\text { sustainable agriculture, healthy, } \\
\text { free of pesticides and that } \\
\text { organized society and responsible } \\
\text { institutions must undertake } \\
\text { actions that meet the needs of } \\
\text { the people who work in the farms } \\
\text { or consume agricultural products } \\
\text { harvested there, especially } \\
\text { controlling risks and consequences } \\
\text { that can and must be avoided. }\end{array}$ & Questionnaire & $\begin{array}{l}\text { Nasrala } \\
\text { Neto, Lacaz } \\
\text { and Pignati }\end{array}$ & 2014 \\
\hline RS & $\begin{array}{l}\text { Poisoning; Mental } \\
\text { disorders }\end{array}$ & $\begin{array}{l}\text { Reinforces the evidence of } \\
\text { the association between } \\
\text { pesticide poisoning and mental } \\
\text { health disorders. It also points } \\
\text { to increased risk of minor } \\
\text { psychiatric disorders from low } \\
\text { socioeconomic status, dermal } \\
\text { pesticide exposure and exposure to } \\
\text { organophosphates. Reveals intense } \\
\text { nicotine exposure as a risk for } \\
\text { tobacco farmers' mental health. }\end{array}$ & $\begin{array}{l}\text { Characterizing } \\
\text { economic indicators } \\
\text { of the farms, socio- } \\
\text { demographic factors, } \\
\text { lifestyle habits } \\
\text { and occupational } \\
\text { exposures. }\end{array}$ & Faria et al. & $2014 b$ \\
\hline
\end{tabular}


Table 1 - Continuation.

\begin{tabular}{|c|c|c|c|c|c|}
\hline State & Target & Major findings & Methodology & Reference & Year \\
\hline SE & $\begin{array}{l}\text { Rural Population; } \\
\text { Quality of life }\end{array}$ & $\begin{array}{l}\text { Agricultural workers users of } \\
\text { pesticides showed the worst levels } \\
\text { of quality of life when compared to } \\
\text { those who have not handled them. } \\
\text { The use of pesticides and their } \\
\text { toxicity class interfered in a most } \\
\text { striking way in the classification of } \\
\text { hearing loss presented by this group. }\end{array}$ & $\begin{array}{l}\text { Audiological } \\
\text { evaluation }\end{array}$ & $\begin{array}{l}\text { Sena, Vargas } \\
\text { and Oliveira }\end{array}$ & 2013 \\
\hline RJ & $\begin{array}{l}\text { Risk Perception; Risk } \\
\text { Communication; } \\
\text { Defensive Strategies; } \\
\text { Community-Based } \\
\text { Participatory Research }\end{array}$ & $\begin{array}{l}\text { Risk perceptions and work } \\
\text { practices are strongly influenced } \\
\text { by local cultural patterns and, } \\
\text { therefore, must be taken into } \\
\text { account when developing effective } \\
\text { intervention strategies, including } \\
\text { risk communication initiatives. }\end{array}$ & Questionnaire & Peres et al. & 2013 \\
\hline RJ & $\begin{array}{c}\text { Small holders; } \\
\text { Environment Human } \\
\text { health }\end{array}$ & $\begin{array}{l}\text { Do not confirm that the } \\
\text { farmers' apparent careless } \\
\text { handling of pesticides is linked } \\
\text { to an intentional disregard for } \\
\text { intoxication risk. The results } \\
\text { point to a more complex set } \\
\text { of explanatory variables that } \\
\text { include: labor scarcity, inadequacy } \\
\text { of protective gear, mixing } \\
\text { practices and limited educational } \\
\text { effectiveness of labeling standards. }\end{array}$ & Questionnaire & $\begin{array}{l}\text { Pedlowskia } \\
\text { et al. }\end{array}$ & 2012 \\
\hline DF & $\begin{array}{l}\text { Knowledge, attitudes, } \\
\text { and practices study; } \\
\text { Acetylcholinesterase; } \\
\text { Butyrylcholinesterase }\end{array}$ & $\begin{array}{l}\text { Although most farmers were } \\
\text { aware that pesticides can harm } \\
\text { their health, many still use PPDs in } \\
\text { an inappropriate manner, or not } \\
\text { at all, during pesticide handling. } \\
\text { Inhibition of ChE activity during } \\
\text { the exposure period for some } \\
\text { farmers was higher than the safe, } \\
\text { indicating that they might be at } \\
\text { risk by the exposure to pesticides } \\
\text { during their agricultural activities. }\end{array}$ & $\begin{array}{l}\text { Questionnaire and } \\
\text { Blood sample }\end{array}$ & Pasiani et al. & 2012 \\
\hline RJ & $\begin{array}{l}\text { Hearing; Auditory } \\
\text { Perception; Adverse } \\
\text { Effects. }\end{array}$ & $\begin{array}{l}\text { Workers exposed to pesticide } \\
\text { performed below-average on } \\
\text { Temporal Auditory Processing tests. } \\
\text { There was association between the } \\
\text { index of exposure to pesticides and } \\
\text { worse performance in Temporal } \\
\text { Auditory Processing tests, suggesting } \\
\text { that pesticides may be harmful to } \\
\text { central auditory pathways. }\end{array}$ & $\begin{array}{l}\text { Questionnaire, } \\
\text { meatoscopy, } \\
\text { basic audiological } \\
\text { evaluation and } \\
\text { temporal auditory } \\
\text { processing tests. }\end{array}$ & Bazilio et al. & 2012 \\
\hline
\end{tabular}


Table 1 - Continuation.

\begin{tabular}{|c|c|c|c|c|c|}
\hline State & Target & Major findings & Methodology & Reference & Year \\
\hline RJ & $\begin{array}{l}\text { Health Indicators; } \\
\text { Rural Labor; Public } \\
\text { Health }\end{array}$ & $\begin{array}{l}\text { The volume of the determinants } \\
\text { identified in the DPSEEA Matrix are } \\
\text { related to deficiencies in actions } \\
\text { for monitoring and surveillance of } \\
\text { pesticide use, as well as the lack of } \\
\text { technical assistance provided by } \\
\text { the Public Sector. }\end{array}$ & $\begin{array}{l}\text { DPSEEA model } \\
\text { (WHO) based on } \\
\text { analysis of official } \\
\text { public documents. }\end{array}$ & $\begin{array}{l}\text { Araújo-Pinto, } \\
\text { Peres and } \\
\text { Moreira }\end{array}$ & 2012 \\
\hline PR & $\begin{array}{l}\text { Poisoning; Economy; } \\
\text { Health expenditures }\end{array}$ & $\begin{array}{l}\text { Society, especially the population } \\
\text { most affected by agrochemicals, } \\
\text { would benefit if the risks of acute } \\
\text { intoxication associated with the } \\
\text { current model of agricultural } \\
\text { production were recognized and } \\
\text { eliminated. }\end{array}$ & $\begin{array}{l}\text { Information obtained } \\
\text { from Pesquisa de } \\
\text { Previsão de Safras } \\
\text { from } 1998 \text { to } 1999 .\end{array}$ & $\begin{array}{l}\text { Soares and } \\
\text { Porto }\end{array}$ & 2012 \\
\hline RJ & $\begin{array}{l}\text { Mortality rates; } \\
\text { Hospitalization rates } \\
\text { attributable to suicide } \\
\text { attempts; Sales of } \\
\text { pesticides }\end{array}$ & $\begin{array}{l}\text { Pesticide exposure may indeed } \\
\text { increase the risk of suicide } \\
\text { frequency, especially among } \\
\text { agricultural workers. }\end{array}$ & $\begin{array}{l}\text { Data on mortality } \\
\text { rates, hospitalization } \\
\text { rates attributable } \\
\text { to suicide attempts, } \\
\text { and data on sales of } \\
\text { pesticides. }\end{array}$ & Meyer et al. & 2010 \\
\hline MG & $\begin{array}{l}\text { Rural Settlements; } \\
\text { Social Conditions; } \\
\text { Family Health; Rural } \\
\text { Health; Food Security; } \\
\text { Rural Population } \\
\text { Health; Landless } \\
\text { Worker Movment. }\end{array}$ & $\begin{array}{l}\text { The view held by families from } \\
\text { the Landless Rural Workers' } \\
\text { Movement was that as they } \\
\text { belonged to the Movement and } \\
\text { were better organized, their health } \\
\text { was better than the temporary } \\
\text { rural workers'. The conservative } \\
\text { modernization of rural Brazil } \\
\text { has led to worse conditions for } \\
\text { temporary rural workers, while } \\
\text { Agrarian Reform has allowed for a } \\
\text { better quality of life and improved } \\
\text { health conditions among families } \\
\text { in the areas under study. }\end{array}$ & Questionnaire & $\begin{array}{l}\text { Carneiro } \\
\text { et al. }\end{array}$ & 2008 \\
\hline RJ & $\begin{array}{l}\text { Environmental } \\
\text { Pollution }\end{array}$ & $\begin{array}{l}\text { Discusses several pesticide-related } \\
\text { implications for human health } \\
\text { and the environment in the } \\
\text { mountainous region of the State of } \\
\text { Rio de Janeiro, an important farming } \\
\text { center. The article presents the } \\
\text { results of the research in the area, } \\
\text { identifying possible determinants of } \\
\text { the current situation and some of } \\
\text { the main challenges in dealing with } \\
\text { the problem. }\end{array}$ & Survey & $\begin{array}{l}\text { Peres and } \\
\text { Moreira }\end{array}$ & 2007 \\
\hline
\end{tabular}


Table 1 - Continuation.

\begin{tabular}{|c|c|c|c|c|c|}
\hline State & Target & Major findings & Methodology & Reference & Year \\
\hline RJ & $\begin{array}{c}\text { Intoxication; } \\
\text { Multiple Application; } \\
\text { Delayed-Neuropathy; } \\
\text { Organophosphate } \\
\text { Pesticides }\end{array}$ & $\begin{array}{l}\text { These results indicate recurrent } \\
\text { multiple overexposures to high } \\
\text { concentrations of different } \\
\text { chemicals, with serious damage } \\
\text { to vital functions, especially } \\
\text { considering their young age } \\
\text { (average } 35 \pm 11 \text { years old) and } \\
\text { the productive period in their } \\
\text { lifetime. }\end{array}$ & $\begin{array}{l}\text { Questionnaire, } \\
\text { biological sample } \\
\text { collection for } \\
\text { toxicology analysis } \\
\text { and clinical - general } \\
\text { and neurological - } \\
\text { assessment. }\end{array}$ & Araújo et al. & 2007 \\
\hline RJ & Neurobehavioral & $\begin{array}{l}\text { While a few Behavioral } \\
\text { Assessment and Research System } \\
\text { (BARS) performance measures } \\
\text { suggested behavioral impairments } \\
\text { for the rural versus the urban } \\
\text { participants, a stronger and more } \\
\text { consistent association between } \\
\text { BARS measures (especially } \\
\text { impairment of tapping, digit span, } \\
\text { and selective attention) and level } \\
\text { of exposure to pesticides was } \\
\text { noted when the exposure index } \\
\text { was input into a multiple linear } \\
\text { regression analysis. Exposure } \\
\text { seemed to be especially strong for } \\
\text { the youngest participants (10-11 } \\
\text { years old). }\end{array}$ & $\begin{array}{l}\text { Questionnaire, } \\
\text { Behavioral } \\
\text { Assessment and } \\
\text { Research System } \\
\text { (BARS) to assess } \\
\text { their performance. }\end{array}$ & $\begin{array}{c}\text { Eckerman } \\
\quad \text { et al. }\end{array}$ & 2007 \\
\hline MS & $\begin{array}{c}\text { Knowledge, Attitude } \\
\text { and Practices (KAP) } \\
\text { survey }\end{array}$ & $\begin{array}{l}\text { About } 92 \% \text { of the interviewees } \\
\text { had worked directly with } \\
\text { pesticides and } 59.6 \% \text { reported } \\
\text { typical intoxication symptoms. } \\
\text { Only } 44.3 \% \text {, however, believe } \\
\text { they had been intoxicated. A } \\
\text { significant correlation was found } \\
\text { between hand washing after } \\
\text { pesticide application and reporting } \\
\text { symptoms. Less than } 20 \% \text { used } \\
\text { masks, impermeable clothes, or } \\
\text { gloves during pesticide application. }\end{array}$ & Questionnaire & Recena et al. & 2006 \\
\hline RJ & $\begin{array}{l}\text { Risk Perception; Risk } \\
\text { Communication; } \\
\text { Women's Health }\end{array}$ & $\begin{array}{l}\text { Results showed that the inclusion } \\
\text { of risk-perception studies in the } \\
\text { development of educative and } \\
\text { risk-communication campaigns is } \\
\text { very important, linking research to } \\
\text { action. }\end{array}$ & Questionnaire & Peres et al. & 2006 \\
\hline
\end{tabular}


Table 1 - Continuation.

\begin{tabular}{|c|c|c|c|c|c|}
\hline State & Target & Major findings & Methodology & Reference & Year \\
\hline RJ & Risk; Rural Population & $\begin{array}{l}\text { Results pointed to the importance } \\
\text { of risk perception analysis } \\
\text { in the process of developing } \\
\text { strategies of intervention in rural } \\
\text { areas, especially in policies and } \\
\text { educational risk communication } \\
\text { campaigns. }\end{array}$ & $\begin{array}{l}\text { Questionnaire and } \\
\text { assessment of local } \\
\text { work processes. }\end{array}$ & $\begin{array}{c}\text { Peres, } \\
\text { Rozemberg } \\
\text { and De Lucca }\end{array}$ & 2005 \\
\hline MS & Suicide; Poisoning & $\begin{array}{l}\text { Poisonings occurred mostly } \\
\text { from October to March } \\
\text { and the organophosphate } \\
\text { insecticides monocrotophos and } \\
\text { methamidophos were the main } \\
\text { pesticides involved. }\end{array}$ & $\begin{array}{l}\text { Reports from } 1992 \\
\text { to } 2002, \text { using } \\
\text { data from the } \\
\text { Integrated Center } \\
\text { for Toxicological } \\
\text { Surveillance under } \\
\text { the State Health } \\
\text { Department. }\end{array}$ & $\begin{array}{l}\text { Pires, Caldas } \\
\text { and Recena }\end{array}$ & 2005 \\
\hline RJ & $\begin{array}{c}\text { Agriculture; Pesticide } \\
\text { Exposure }\end{array}$ & $\begin{array}{l}\text { Highlights health professionals' } \\
\text { discourse in relation to } \\
\text { the association between } \\
\text { "nervousness" and pesticides. The } \\
\text { authors discuss factors related to } \\
\text { this perception and make several } \\
\text { suggestions for future research. }\end{array}$ & Questionnaire & $\begin{array}{l}\text { Levigard e } \\
\text { Rozemberg }\end{array}$ & 2004 \\
\hline RS & $\begin{array}{l}\text { Pesticide Exposure; } \\
\text { Incidence }\end{array}$ & $\begin{array}{l}\text { Based on Poison regression, } \\
\text { applying pesticide, reentering } \\
\text { crop fields after spraying and } \\
\text { working with pesticides in more } \\
\text { than one farm were the types } \\
\text { of exposure that presented a } \\
\text { positive correlation with pesticide } \\
\text { poisoning. }\end{array}$ & Questionnaire & Faria et al. & 2004 \\
\hline MG & $\begin{array}{l}\text { Risk Factors; } \\
\text { Poisoning; Rural } \\
\text { Health }\end{array}$ & $\begin{array}{l}\text { The results emphasize the high } \\
\text { level of health risk associated to } \\
\text { pesticide use among rural workers. }\end{array}$ & $\begin{array}{l}\text { Questionnaire. } \\
\text { Data obtained } \\
\text { through the Jorge } \\
\text { Duprat Figueiredo } \\
\text { Foundation for } \\
\text { Workers' Safety } \\
\text { and Occupational } \\
\text { Medicine. }\end{array}$ & $\begin{array}{c}\text { Soares, } \\
\text { Almeida and } \\
\text { Moro }\end{array}$ & 2003 \\
\hline MG & Economic Assessment & $\begin{array}{l}\text { Points to the need for an } \\
\text { extensive investigation on the real } \\
\text { benefits of pesticide use and its } \\
\text { consequences for the environment } \\
\text { and health in Brazil. }\end{array}$ & $\begin{array}{l}\text { Data were } \\
\text { obtained from } \\
\text { the Fundacentro } \\
\text { Ministry of Work } \\
\text { agency for the years } \\
\text { 1991-2000 }\end{array}$ & $\begin{array}{l}\text { Soares, Moro } \\
\text { and Almeida }\end{array}$ & 2002 \\
\hline
\end{tabular}


Table 1 - Continuation.

\begin{tabular}{|c|c|c|c|c|c|}
\hline State & Target & Major findings & Methodology & Reference & Year \\
\hline RJ & $\begin{array}{c}\text { Communication; Health } \\
\text { Education; Interview; } \\
\text { Communication and } \\
\text { Health. }\end{array}$ & $\begin{array}{l}\text { This study pointed out to the } \\
\text { historical misinformation on } \\
\text { pesticides in rural areas. }\end{array}$ & Questionnaire & Peres et al. & 2001 \\
\hline RJ & $\begin{array}{l}\text { Insecticides; } \\
\text { Organophosphate; } \\
\text { Poisoning; } \\
\text { Socioeconomic } \\
\text { Factors; Carbamates; } \\
\text { Cholinesterase } \\
\text { Inhibitors; Blood. }\end{array}$ & $\begin{array}{l}\text { A result of } 3.0 \% \text { was found for } \\
\text { the BChE values, and } 41.8 \% \text {, } \\
\text { according to AChE. Individuals } \\
\text { with at least one positive } \\
\text { enzymatic indicator result were } \\
\text { considered as "intoxicated". When } \\
\text { these data were compared to the } \\
\text { social-economic and pesticides } \\
\text { use factors, the importance of the } \\
\text { educational level in the prevalence } \\
\text { of intoxication was highlighted. }\end{array}$ & $\begin{array}{c}\text { AChE and } \mathrm{BChE} \\
\text { activities }\end{array}$ & $\begin{array}{l}\text { Oliveira-Silva } \\
\text { et al. }\end{array}$ & 2001 \\
\hline PE & $\begin{array}{l}\text { Tomatoes; } \\
\text { Environment Impacts; } \\
\text { Health Surveillance. }\end{array}$ & $\begin{array}{l}\text { There is a lack of effective policies to } \\
\text { protect the health of rural workers } \\
\text { who must deal with pesticides and } \\
\text { the environment which has already } \\
\text { been severely damaged. }\end{array}$ & Questionnaire & $\begin{array}{c}\text { Araújo, } \\
\text { Nogueira } \\
\text { and Augusto }\end{array}$ & 2000 \\
\hline RS & $\begin{array}{l}\text { Pesticide Poisoning; } \\
\text { Occupational } \\
\text { Accidents; Agriculture }\end{array}$ & $\begin{array}{l}\text { The high prevalence of health } \\
\text { problems identified in the study } \\
\text { calls attention to the need for } \\
\text { measures to promote and protect } \\
\text { rural workers' health. }\end{array}$ & Questionnaire & Faria et al. & 2000 \\
\hline RS & $\begin{array}{c}\text { Mental Health; } \\
\text { Poisoning; Educational } \\
\text { Status. }\end{array}$ & $\begin{array}{l}\text { The results call attention to the } \\
\text { problem's dimension and to the } \\
\text { importance of adopting new } \\
\text { policies to protect farm workers' } \\
\text { mental health. }\end{array}$ & Questionnaire & Faria et al. & 1999 \\
\hline RJ & $\begin{array}{l}\text { Ddt; Dieldrin; } \\
\text { Occupational } \\
\text { Exposure }\end{array}$ & $\begin{array}{l}\text { Serum concentrations of } \\
\text { organochlorine pesticides found } \\
\text { in this study are comparable to } \\
\text { the levels reported for the non- } \\
\text { occupationally exposed population } \\
\text { in Brazil and elsewhere. }\end{array}$ & $\begin{array}{l}\text { Blood samples, } \\
\text { Serum levels of } \\
\text { organochlorine } \\
\text { pesticides measured. }\end{array}$ & $\begin{array}{c}\text { Paumgartten } \\
\text { et al. }\end{array}$ & 1998 \\
\hline BA & $\begin{array}{l}\text { Occupational and } \\
\text { Environmental } \\
\text { Exposure }\end{array}$ & $\begin{array}{l}\text { Rural workers and public health } \\
\text { authorities must become aware } \\
\text { of the importance of protective } \\
\text { equipment, periodic health } \\
\text { examinations and reduced } \\
\text { environmental pollution in order } \\
\text { to lessen occupational risks of field } \\
\text { workers and promote improved } \\
\text { conditions of life for the rural } \\
\text { population. }\end{array}$ & $\begin{array}{l}\text { Parameters of } \\
\text { biochemistry, } \\
\text { hematology, and } \\
\text { organochlorine } \\
\text { insecticide residues } \\
\text { in the blood. }\end{array}$ & Carvalho & 1991 \\
\hline
\end{tabular}


Table 1 - Continuation.

\begin{tabular}{|c|c|c|c|c|c|}
\hline State & Target & Major findings & Methodology & Reference & Year \\
\hline SP & $\begin{array}{l}\text { CNS Magnese } \\
\text { Intoxication }\end{array}$ & $\begin{array}{l}\text { Occupational exposure to pesticides } \\
\text { containing } \mathrm{Mn} \text { is a possible source } \\
\text { of } \mathrm{Mn} \text { intoxication of the CNS. }\end{array}$ & Mn intoxication & Ferraz et al. & 1988 \\
\hline \multicolumn{6}{|c|}{ CANCER, GENOTOXICITY, DNA DAMAGE, OXIDATIVE STRESS } \\
\hline SP & $\begin{array}{c}\text { Machine Learning; } \\
\text { Genotoxicity } \\
\text { Micronucleus; } \\
\text { Smoking; Agriculture }\end{array}$ & $\begin{array}{l}\text { Exposing agricultural workers } \\
\text { to pesticides and/or tobacco } \\
\text { had genotoxic potential, but } \\
\text { concomitant exposure to } \\
\text { xenobiotics did not lead to } \\
\text { additive or potentiating effects. }\end{array}$ & $\begin{array}{l}\text { Oral mucosa cells, } \\
\text { cytogeneticanalysis }\end{array}$ & $\begin{array}{l}\text { Tomiazzi } \\
\text { et al. }\end{array}$ & 2018 \\
\hline SC & $\begin{array}{l}\text { DNA Damage; } \\
\text { Oxidative Stress }\end{array}$ & $\begin{array}{c}\text { Exposed individuals, participants } \\
\text { of this study, are more subject } \\
\text { to suffer genetic damage and, } \\
\text { consequently, more susceptible } \\
\text { to diseases resulting from such } \\
\text { damages }\end{array}$ & $\begin{array}{l}\text { Blood samples, } \\
\text { comet assay and } \\
\text { the cytokinesis- } \\
\text { block micronucleus } \\
\text { technique and } \\
\text { thiobarbituric acid } \\
\text { reactive substance } \\
\text { and catalase activity. }\end{array}$ & $\begin{array}{l}\text { Hilgert } \\
\text { Jacobsen- } \\
\text { Pereira et al. }\end{array}$ & 2018 \\
\hline MG & $\begin{array}{l}\text { Genotoxicity Test; } \\
\text { Bioindicators and } \\
\text { Clinical Evaluation }\end{array}$ & $\begin{array}{l}\text { The group exposed to } \\
\text { organophosphates presented } \\
\text { significant changes in all these } \\
\text { parameters compared to the control } \\
\text { group and showed significant } \\
\text { changes in budding, condensed } \\
\text { chromatin and karyolytic cells } \\
\text { compared to the group non- } \\
\text { exposed to organophosphates. Data } \\
\text { from clinical evaluation showed } \\
\text { significant changes in the central } \\
\text { nervous, respiratory and auditory } \\
\text { systems. }\end{array}$ & $\begin{array}{l}\text { Blood, urine and } \\
\text { buccal samples, } \\
\text { activities of } \\
\text { cholinesterases, } \\
\text { the levels of urinary } \\
\text { dialkyl phosphates, } \\
\text { genotoxicity data, } \\
\text { from a cytome assay. }\end{array}$ & Silvério et al. & 2017 \\
\hline $\mathrm{RS}$ & $\begin{array}{l}\text { Skin Neoplasms; } \\
\text { Occupational } \\
\text { Risks; Oncology } \\
\text { Nursing; Clinical } \\
\text { Competence; Health } \\
\text { Communication }\end{array}$ & $\begin{array}{l}\text { This study's results allowed } \\
\text { to clarify the combination of } \\
\text { clinical knowledge and risk } \\
\text { communication regarding skin } \\
\text { cancer to rural workers. }\end{array}$ & $\begin{array}{l}\text { Observational- } \\
\text { exploratory study }\end{array}$ & $\begin{array}{l}\text { Cezar-Vaz } \\
\text { et al. }\end{array}$ & 2015 \\
\hline RS & $\begin{array}{l}\text { Oxidative stress, } \\
\text { TBARS, protein } \\
\text { carbonyls. }\end{array}$ & $\begin{array}{l}\text { The results demonstrated a } \\
\text { change in the oxidative status of } \\
\text { rural workers compared to the } \\
\text { control group, mainly by possible } \\
\text { inhibition of AChE activity and } \\
\text { the occurrence of oxidative stress } \\
\text { without showing changes in } \\
\text { biochemical parameters. }\end{array}$ & $\begin{array}{l}\text { Questionnaire and } \\
\text { blood sample }\end{array}$ & $\begin{array}{l}\text { Murussi } \\
\text { et al. }\end{array}$ & 2014 \\
\hline
\end{tabular}


Table 1 - Continuation.

\begin{tabular}{|c|c|c|c|c|c|}
\hline State & Target & Major findings & Methodology & Reference & Year \\
\hline RJ & $\begin{array}{l}\text { Brain Cancer; Age- } \\
\text { Period-Cohort; } \\
\text { Agriculture; Trend }\end{array}$ & $\begin{array}{l}\text { There is an increasing trend in } \\
\text { brain cancer mortality rates in } \\
\text { the rural Serrana Region in Brazil. } \\
\text { At the ecological level, different } \\
\text { environmental factors, especially } \\
\text { the use of pesticides, may explain } \\
\text { regional disparities in the mortality } \\
\text { patterns from brain cancers. }\end{array}$ & $\begin{array}{l}\text { Descriptive study } \\
\text { examined brain } \\
\text { cancer mortality who } \\
\text { died between } 1996 \\
\text { and } 2010 .\end{array}$ & $\begin{array}{l}\text { Miranda } \\
\text { Filho et al. }\end{array}$ & 2014 \\
\hline GO & $\begin{array}{c}\text { Occupational } \\
\text { Exposure; DNA } \\
\text { Damage; MN Comet } \\
\text { Assay }\end{array}$ & $\begin{array}{l}\text { Occupational exposure to } \\
\text { pesticides could cause genome } \\
\text { damage in somatic cells, } \\
\text { representing a potential health risk } \\
\text { to rural workers that constantly } \\
\text { deal with agrochemicals without } \\
\text { adequate personal protection } \\
\text { equipment. }\end{array}$ & $\begin{array}{l}\text { Micronucleus and } \\
\text { the comet assay. }\end{array}$ & Khayat et al. & 2013 \\
\hline GO & $\begin{array}{c}\text { Polymorphism GST; } \\
\text { Biomarkers }\end{array}$ & $\begin{array}{l}\text { The authors could not associate } \\
\text { a null GSTT1 or null GSTM1 } \\
\text { polymorphisms or both to } \\
\text { intoxication events caused by } \\
\text { pesticides, but instead they } \\
\text { presented the importance of using } \\
\text { Personal Protection Equipment to } \\
\text { prevent such harm. }\end{array}$ & Blood sample & Godoy et al. & 2014 \\
\hline CE & $\begin{array}{l}\text { Biomonitoring; } \\
\text { Human Lymphocytes; } \\
\text { Comet Assay; } \\
\text { Chromosomal } \\
\text { Aberrations }\end{array}$ & $\begin{array}{l}\text { Damages caused by pesticides } \\
\text { in our study area were not great } \\
\text { enough to induce permanent } \\
\text { mutations or to interfere with } \\
\text { mitotic apparatus formation; } \\
\text { minimal pesticide damages } \\
\text { could have undergone cellular } \\
\text { repair, explaining the absence } \\
\text { of structural and numerical } \\
\text { chromosome aberration. }\end{array}$ & $\begin{array}{c}\text { Alkaline comet assay } \\
\text { and the chromosome } \\
\text { aberration test. }\end{array}$ & Paiva et al. & 2011 \\
\hline $\mathrm{PE}$ and $\mathrm{AL}$ & $\begin{array}{l}\text { Carcinogenesis; } \\
\text { Analysis of Principal } \\
\text { Components }\end{array}$ & $\begin{array}{l}\text { Both endosulfan and its } \\
\text { metabolites are electrophilic and } \\
\text { have carcinogenic potential. }\end{array}$ & $\begin{array}{l}\text { Electronic } \\
\text { paramenters } \\
\text { (Electron affinity, } \\
\text { dipole moments, } \\
\text { electrostatic } \\
\text { attaction, } \\
\text { formation heat and } \\
\text { permeability of the } \\
\text { cell membrane). }\end{array}$ & Bedor et al. & 2010 \\
\hline
\end{tabular}


Table 1 - Continuation.

\begin{tabular}{|c|c|c|c|c|c|}
\hline State & Target & Major findings & Methodology & Reference & Year \\
\hline SP & $\begin{array}{l}\text { Cancer; } \\
\text { Agriculture; }\end{array}$ & $\begin{array}{l}\text { Cancers of the skin and digestive } \\
\text { system were the most prevalent. }\end{array}$ & $\begin{array}{l}\text { Database containing } \\
\text { records of Amaral } \\
\text { Carvalho Hospital. }\end{array}$ & $\begin{array}{l}\text { De Brito Sá } \\
\text { Stopelli and } \\
\text { Crestana }\end{array}$ & 2005 \\
\hline RJ & $\begin{array}{l}\text { Mortality; Cancer; } \\
\text { Ecological analysis }\end{array}$ & $\begin{array}{l}\text { Agricultural workers } 30-49 \\
\text { years old showed higher, but not } \\
\text { statistically significant, mortality } \\
\text { by stomach, esophagus, liver, } \\
\text { testis, and prostate cancer, and } \\
\text { soft-tissue sarcoma in the period } \\
\text { of } 1979-1988 \text {, and by testis and } \\
\text { penis cancer, leukemia, and soft- } \\
\text { tissue sarcoma in the period of } \\
\text { 1989-1998. }\end{array}$ & $\begin{array}{c}\text { National Mortality } \\
\text { Information System } \\
\text { between } 1979 \text { and } \\
1998\end{array}$ & Meyer et al. & 2003 \\
\hline SP & $\begin{array}{l}\text { Chromosome } \\
\text { Aberrations; } \\
\text { Toxicology; } \\
\text { Contamination. }\end{array}$ & $\begin{array}{l}\text { Although workers used protection } \\
\text { against the pesticide's fog, the } \\
\text { results revealed that they were } \\
\text { contaminated with the pesticides. }\end{array}$ & $\begin{array}{c}\text { Toxicological dosages } \\
\text { of copper, zinc and } \\
\text { manganese, hepatic } \\
\text { enzyme dosage and } \\
\text { acetylcholinesterase } \\
\text { activity }\end{array}$ & Brega et al. & 1998 \\
\hline
\end{tabular}

Agricultural Workers; Anogenital

RS Herbicides; Distance; Fungicides; Reproductive Hormones; Sperm Quality
Chronic occupational exposure to modern pesticides, particularly herbicides and fungicides, may adversely affect semen quality in young male farmers, potentially leading to poorer morphology. Also, exposure to agricultural pesticides may acutely increase prolactin and chronically alter sex hormone levels acting at the pituitary level through prolactin and LH suppression, hampering compensatory responses to testicular dysfunction.

\section{Seem to support the known} capacity of organochlorines pesticides to exert estrogenic and anti-androgenic activity, affecting sex hormone systems through mechanisms of action that may be different for each individual compound.
Reproductive hormones, semen Cremonese quality, and genital et al. 2017 measures
Interviews and blood sample.
Freire et al.

2014

$$
\begin{gathered}
\text { Organochlorines; } \\
\text { Testosterone }
\end{gathered}
$$


da Educação). The majority of the articles are related to health disorders and occupational health, such as mental disorders, asthma, hearing, suicide, and poisoning.

Reflecting the importance of agriculture to the country's economy, Brazil has a vast legislation specifically designed to regulate the stages of the agrochemicals' life cycle at Federal and State level (GONÇALVES, 2016). All states have a pesticides register and authorization in their territory, but it also left some open controversial points regarding evaluation parameters and the attribution of inspection to the public power (GONÇALVES, 2016). Consequently, according to Pelaez, Terra and Silva (2010) there is a conflict of interests due to the ability of regulators, regulated companies and the companies themselves in adapting to the more stringent criteria for registering toxic substances (PELAEZ; TERRA; SILVA, 2010; GONÇALVES, 2016). There are studies that prove the contamination caused by the indiscriminate use of

\section{Health disorders and Occupational health}

As a result of the analysis of the selected articles, four thematic categories emerged, the first three being linked to the problems that the use or misuse of pesticides generate to the environment and human health and a category linked to the appropriate practices:

- Health disorders and Occupational health;

- Genotoxicity of pesticides;

- Reproductive hormones and Sperm quality;

- Practices to reduce exposure.

Using AChE and BChE analysis, Oliveira-Silva et al. (2001), evaluated the exposures of rural workers of Rio de Janeiro State to anticholinesterasic pesticides. According to the authors' results and to the enzymatic indicator used, data were distinct concerning the incidence of excessive exposure. In the studied sample, a result of $3.0 \%$ was found for $\mathrm{BChE}$ values, and $41.8 \%$ according to AChE. Individuals with at least one positive enzymatic indicator result were considered as "intoxicated". Considering these data and comparing them to the social-economic and pesticides use factors, the importance of educational level in the prevalence of intoxication was showed. The other indicators pesticides in different regions of Brazil (ALBUQUERQUE et al., 2016; CALDAS; ZANELLA; PRIMEL, 2011; RISSATO et al., 2007; LAABS et al., 2002; CALDAS et al., 1999; Laabs et al., 2002; ALHO; VIEIRA, 1997); however, this gap between Brazilian and state legislation leads to a panorama of uncertainties about the extent and degree of environmental contamination, as well as the dimension of effects to the human health and to the environment. Since there are no equal control procedures throughout the national territory, there are vulnerabilities associated with the use of agrochemicals. The European Union, one of the world's largest food producers and holding the position of the world's largest wheat producer, is in the process of implementing the world's most rigorous plan to reduce the use of pesticides. It culminated in the adoption of the Directive 2009/128/CE on the sustainable use of pesticides, whose complete implementation is planned for 2020 (GONÇALVES, 2016).

studied did not show any significant and evident correlation (OLIVEIRA-SILVA et al., 2001). In the same way, Pasiani et al. (2012) conducted a knowledge, attitudes, and practices (KAP)/biomonitoring study in an agricultural setting in Midwestern Brazil. For this purpose, they assessed the knowledge, attitudes, and practices regarding the use of pesticides by farmers in two rural settings and calculated the farmers and residents' levels of exposure to organophosphorous and carbamate pesticides through red cells (AChE) and plasmatic butyrilcholinesterase (BChE) analysis. In relation to these last analyses, for some farmers, the authors found higher activity of cholinesterase inhibition during the exposure period compared to what is considered safe. This may indicate that they might be at risk by the exposure to pesticides during their agricultural activities. AChE activity depletion was also found in family farming settings, and thus may also be at risk from secondary exposure to pesticides (PASIANI et al., 2012).

From an epidemiological, clinical and laboratory aspects study of multiple exposure to pesticides in a representative sample of 102 small farmers, Araújo et al. (2007), brought some light to moderate episodes of acute intoxication by organophosphorates either described by the farmers or observed during clinical examination. Thirteen cases of delayed neuropathies were diag- 
nosed and 29 cases of neural behavioral syndromes and psychiatric disorders associated to the continued use of pesticides. From these results, they found recurrent multiple overexposures to high concentrations of

\section{Genotoxicity of pesticides}

The harmful effects on the health of rural workers, who are chronically exposed to mixtures of agrochemicals, are still little elucidated. In Brazil, Antonucci e Syllos (2000) found a positive relationship between genotoxicity and farmers in Parana, and Silva et al. (2008) in winery workers in Rio Grande do Sul, being observed chromosomal aberrations as genotoxicity markers (SILVA, 2012).

Among the most serious damage caused by pesticides, genotoxicity or genetic toxicology seeks to identify the action of agents that produce toxic and genotoxic effects on the genetic material. From the interaction between our genetic material and genotoxic agents, the formation of adducts, oxidative alterations or even the breakdown of DNA molecules can happen (SILVA, 2012). The elimination of this cell or its repair by the organism usually occurs, however, if the lesion is fixed it will probably cause mutations, that is, hereditary alterations. Thus, there will be a mutagenic effect, where during the replication process the perpetuation of the mutation in the daughter cells will take place (OBE et al., 2002; SILVA, 2012).

The mutagenic potential is common between the pesticides, being extremely toxic to mammals. Because they inhibit the enzyme acetylcholinesterase, Organophosphorus insecticides, for example, cause an accumulation of acetylcholine in nervous tissues, impairing neurotransmission. Therefore, a reaction with DNA molecules occurs, being able to generate substitutions of bases (GRISOLIA, 2005; SILVA, 2012). In 2006, the International Agency for Research on Cancer (IARC) came to consider the organophosphate Dichlorvos as possibly carcinogenic to man (SILVA, 2012).

It is of vital importance to increase studies that seek the detection of cytogenetic damage caused by pesticides, since there is a strong association between occupational exposure to pesticides and different types of cancer (SILVA, 2012). Between them, we can highlight lung cancer (BEANE FREEMAN et al., 2005), bladder (VIEL; CHALLIER, 1995), pancreas (ANDREOTTI et al., different chemicals that may cause serious damage to vital functions, if considered their young age (average $35 \pm 11$ years old) and the productive period in their lifetime (ARAÚJO et al., 2007).

2009) and leukemias (BONNER et al., 2010) (SILVA, 2012). Mechanisms of action between mutagenesis and carcinogenesis may be related. As a consequence of the damage, the mutation may be the initial stage in the process by which most chemical carcinogens initiate tumor formation (RIBEIRO; SALVADORI; MARQUES, 2003; SILVA, 2012). Therefore, genotoxicity and mutagenicity assays for a given pesticide are important for cancer risk assessment. However, they do not have the capacity to predict their carcinogenic potential (SILVA, 2012).

Important and recent articles involving this area are from Tomiazzi et al. (2018), Hilgert Jacobsen-Pereira et al. (2018) and Silvério et al. (2017), performed in SP, SC and MG, respectively. In Tomiazzi et al. (2018), the authors study the relationship between the exposure to two xenobiotics with possible carcinogenic potential. In the exposed groups, the total number of cytogenetic abnormalities and $\mathrm{MN}$ were higher and the exposure to pesticides proved to be more deleterious than smoking. This finding is consistent with the exposure to a mixture of pesticides in the workplace, including compounds that are potentially carcinogenic in humans, as reported by pesticide group and smoking + pesticide group participants (TOMIAZZY et al., 2018).

Results obtained by Hilgert Jacobsen-Pereira et al. (2018) indicate the presence of genotoxic and mutagenic effects in the exposed group. Continuous and low dose exposure to complex mixtures of pesticides is associated to single and double strand breaks of DNA, oxidative stress and crosslinks. It is important to highlight that DNA damage, when incorrectly or not repaired, can persist and accumulate, triggering mutagenic processes and causing important cytogenetic changes (BENEDETTI et al., 2013; HILGERT JACOBSEN-PEREIRA et al., 2018).

From a study in southern Minas Gerais, Silvério et al. (2017) showed that workers had a hazardous exposure to organophosphates and afforded valuable data to es- 
timate the risk to cancer development. The biomarkers used in this study are useful to assess and distinguish

\section{Reproductive hormones and Sperm quality}

It is interesting to highlight two studies approaching reproductive hormones and sperm quality (CREMONESE et al., 2017; FREIRE et al., 2014). Cremonese et al. (2017) investigated reproductive hormone levels, sperm quality, and genital measures in rural compared to urban young men in the South of Brazil, examining their association with occupational exposure to agricultural pesticides. According to their results, the main findings were:

- the linear dose-response relationship's poorer sperm morphology and life time use of all pesticides, fungicides, insecticides, herbicides, OP insecticides, dithiocarbamates and other chemical lasses, mancozeb, glyphosate, and paraquat;

- the association of lifetime use of pesticides, particularly herbicides and fungicides, with reduced levels of $\mathrm{LH}$ and prolactin;

- the association of rural living and maternal farming during pregnancy with larger anogenital distance and testicular volume, but poorer sperm morphology.

\section{Practices to reduce exposure}

According to the World Health Organization, accidental poisoning kills about 355,000 people every year. Two thirds of these deaths happen in developing countries and are strongly associated with overexposure and inappropriate use of toxic chemicals, including pesticides (WHO, 2008; GONÇALVES, 2016). The use of pesticides has increased worldwide in the last decades, representing a risk for several diseases in humans, including cancer. As previously mentioned, genotoxicity underscores the importance of increasing studies that seek to detect cytogenetic damage caused by pesticides. It is among the most serious damage caused by pesticides, as there's a strong association between occupational exposure to pesticides and different types of cancer.

The inappropriate use of pesticides is of vital importance and is considered one of the main public health problems, mainly in the interior of Brazil. There are few, however, valuable studies related to the characteristics of their occupational use in order to identify the effects of the agrochemicals' use by rural workers from basic science with the occupational and environmental exposure to pesticides (SILVÉRIO et al., 2017).

The authors suggest that chronic occupational exposure to modern pesticides, particularly herbicides and fungicides, may adversely affect semen quality in young male farmers in the South of Brazil, potentially leading to poorer morphology (CREMONESE et al., 2017).

On the other hand, Freire et al. (2014) aimed to examine the association between serum concentrations of organochlorine pesticides and levels of sex hormones in adult population in a rural area of Brazil heavily contaminated with these pesticides. The authors found an inverse association between organochlorine pesticide concentrations and testosterone in men and LH and FSH in peri-/postmenopausal women, together with the high proportion of women with elevated prolactina. Based on their findings, the authors suggest that, in this population, these organochlorine compounds may have triggered anti-androgenic effects in men and estrogenic effects in women (FREIRE et al., 2014).

enough relevance to give a return to society's health. Therefore, it is necessary to obtain a profile of the rural worker through the study on the use of agrochemicals' impact, as well as the possible genetic and cytological modifications that can be triggered by these treatments.

According to Abreu \& Alonzo (2014), the chemical industries encourage the expansion of the use of their products through aggressive marketing and commercialization practices, supported by the Brazilian legislation on agrochemicals (PORTO \& SOARES, 2012; MIRANDA et al., 2007). They disregard the health impacts on farmers by promoting "safe use" (ABREU \& ALONZO, 2014). The safety manuals prepared by the Associação Nacional de Defesa Vegetal (IWAMI et al., 2010; ASSOCIAÇÃO NACIONAL DE DEFESA VEGETAL, 2006) credit the hazards and accidents involved in the handling of pesticides to the "incorrect use" by the worker and not to the toxicity of the formulations and to the imposition of the agrochemical model of production in the Country (BREIHL, 2003; ABREU \& ALONZO, 2014). 
Quite common for rural workers, mainly by poor communication of risks to the population, is mixing active substances with the objective of achieving a potent effect, the so-called cocktail effect (REFFSTRUP; LARSEN; MEYER, 2010; HERNÁNDEZ et al., 2013; GONÇALVES, 2016). Individually, these active substances can be approved but mixed imply greater risks. Brazilian legislation does not provide tests on the effects of that, which are frequent and rarely punished. Although already regulated in several States, there is an urgent need to spread the information about the risks of using agrochemicals to the population and gain national dimension (GONÇALVES, 2016).

Stoppelli \& Magalhães (2005), cited some strategies to minimize negative impacts to the producer and consumer: greater inspection of manufacturing, import, export and quality, as well as products sales; greater control over use, including correct disposal of empty packaging and waste; application only when necessary, in the correct dose and preferring less toxic formulations; greater control in commercialized foods; restrictions by the responsible organs of those products without full epidemiological and environmental studies; banning, when necessary, classes of pesticides; simplifying labels on packaging; risk communication; changes in the production and labor model; greater adequacy of protective equipment to excessive heat in tropical countries. Also incentive to government policies that incorporate, before crediting these products, an earlier structuring of the system, such as the preparation of labor, certification of Good Agricultural Practices and compliance with laws and improvements in inspection (STOPPELLI \& MAGALHÃES, 2005).

As reported by Maroni, Fait and Colosio (1999), in the European Union a set of tests is required and designed to identify a toxicological profile of the substance. This profile includes: acute toxicity (oral, inhalation, dermal), skin and eye irritation, skin sensitization, short-term toxicity (28-90 days), mutagenicity, long-term toxicity ( 2 years), carcinogenicity, reproductive toxicity and other special effects (MARONI; FAIT; COLOSIO, 1999). According to the same author, developed countries' stringent requirements have to be satisfied before a product is authorized and the costs of meeting these requirements are very high. With the lack of legislation and adequate control's infrastructure to enforce legislation mainly in developing countries, the rural worker, often misinformed, starts to use pesticides that contain dangerous compounds which do not have controlled adverse effects both to humans and to the environment (MARONI; FAIT; COLOSIO, 1999).

The production of organic products through price reduction policies is also worth highlighting as a possible measure to be taken. According to Soares (2010), as it is done with alcohol and cigarettes in Brazil, making the production of pesticides less attractive by charging the products with high toxicity could be done. Having less than $1 \%$ of accredited establishments, the organic market in Brazil is considered very shy (IBGE, 2006; SOARES, 2010). Already in Europe, mainly due to the implemented policies encouraged the expansion of this market. About $11 \%$ of the land used for agriculture in Austria is occupied by certified organic producers, 7 to $10 \%$ in the Czech Republic, Greece, Italy, Sweden and Switzerland, 4 to $6 \%$ in Denmark, Estonia, Germany, Finland, Lithuania, Portugal, Slovakia, Slovenia, Spain and the United Kingdom, and less than 3\% in other countries (PADEL; RÖCKLINSBERG; SCHMID, 2009; SOARES, 2010).

\section{CONCLUSION}

Rural workers and planting care are associated with a variety of occupational health hazards, both by physical factors and extreme weather conditions, and by exposure to hazards arising from the use of toxicological chemicals, such as pesticides and fertilizers. There are also biological and mechanical risks. Farmers are involved in different farming activities, so they are susceptible to numerous work-related health disorders. In many cases, producers do not give adequate attention to preventing and controlling occupational health problems. For the rural environment, comprehensive occupational health programs are adequately developed for this public, involving both preventive, curative and rehabilitation aspects. Studies such as Chaudhuri (2000), Cavalheiro et al. (2014) and Rempel, Haetinger and Sehnem (2013) demonstrate that there are health problems related to the occupational health of rural producers and that they demonstrate that specific programs can improve their quality of life. 
Several studies report and describe the genotoxic effect of pesticides on farmers who use them, including a study by Doğanlar et al. (2018), which shows that populations of areas close to sites that use agrotoxic, even if they are not in contact with them, present an increase in the genotoxicity verified in blood test. These same authors suggest that biological monitoring efforts should be made to control non-occupational exposure to pesticides and thus safeguarding the health of agricultural residents. Despite the possible immediate benefits of using pesticides, it is important to stress that they are toxic substances and that their uncontrolled use causes severe damage to environmental and human health (GONÇALVES, 2016). Many countries encourage sustainable agricultural practices and have restrictions on importing products without proven food security. Therefore, even if the elimination of pesticide use in agriculture is still far away, its use in a rational manner and respecting quantity, application, environmental legislation and with appropriate PPE use, make the genotoxic risks smaller.

Most articles that relate the change in reproductive hormones and sperm quality to the prolonged use of pesticides in agriculture also mention that pregnant women exposed to pesticides accumulate active ingredients and pass them to the fetus. In a study carried out with rural producers in a city in the interior of Rio Grande do Sul, they do not relate the inadequate use of pesticides to their health status, even though they know the problems that pesticides can have on their health (WAHLBRINCK; BICA; REMPEL, 2017).

Many countries, mainly from the European Union, have adopted targets to reduce the use of agrochemicals, but countries that have their agriculture heavily depen- dent on pesticides must follow the regulations of the US EPA, which is the agency that regulates the amount of pesticide residues considered to be reliable in food. These sustainable environmental measures and practices, such as crop rotation and crop diversity, are necessary to ensure that even using only pesticides, there is less risk of generating health problems. Also, the measures adopted by the EU can be adapted to the Brazilian reality, improving the Brazilian agrochemicals' management system and for the Brazilian products to be certified and accepted in the European market.

This review made it possible to understand the current situation of the association between the exposure to pesticides and their possible effects caused to Brazilian rural workers. Considering the size of the country and although the research on the impact of the use of pesticides on human health has grown in recent years, it is still insufficient to really know the dimension of their damage on human health, caused by occupational exposure and by the intensive use of agrochemicals. It is fundamental to identify the presence of genotoxic and mutagenic effects of the use of pesticides in rural workers, considering the strong relationship between mutagenesis and carcinogenesis in pesticide users, as well as other damages involving health disorders and reproductive hormones.

Brazil has been growing in relation to the consumption of agrochemicals as well as in the production and export of agricultural products. It is up to us, and mainly to the governments, the search for the disciplining of their use, preventive actions and change to an agriculture aware of the environmental health, the consumer and the rural worker (STOPPELLI \& MAGALHÃES, 2005).

\section{CONFLICT OF INTERESTS}

The authors confirm that this article content has no conflicts of interest.

\section{FUNDING SOURCES}

This study was financed in part by the Brazilian Coordination for the Improvement of Higher Education Per- sonnel (Coordenação de Aperfeiçoamento de Pessoal de Nível Superior-CAPES), Finance Code 001.

\section{ACKNOWLEDGMENTS}

The first author is grateful for the Postdoctoral grant from CAPES. 


\section{REFERENCES}

ABREU, P. H. B.;ALONZO, H. G. A. Trabalho rural e riscos à saúde: uma revisão sobre o "uso seguro" de agrotóxicos no Brasil. Ciência \& Saúde Coletiva, v. 19, n. 10, p. 4197-4208, 2014. http://dx.doi.org/10.1590/1413-812320141910.09342014

AGRONEWS. Top Six Agrochemical Firms Grew Steady 2013. AgroNews, 2014. Available at: <http://news.agropages. com/News/NewsDetail---11846-e.htm>. Acessed on: Nov., 2018.

ALBUQUERQUE, A. F.; RIBEIRO, J. S.; KUMMROW, F.; NOGUEIRA, A. J.; MONTAGNER, C. C.; UMBUZEIRO, G. A. Pesticides in Brazilian freshwaters: a critical review. Environmental Science: Process \& Impacts, v. 18, n. 7, p. 779-787, 2016. http://dx.doi.org/10.1039/c6em00268d

ALHO, C. J. R.; VIEIRA, L. M. Fish and wildlife resources in the pantanal wetlands of Brazil and potential disturbances from the release of environmental contaminants. Environmental Toxicology and Chemistry, v. 16, n. 1, p. 71-74, 1997. https://doi.org/10.1002/etc.5620160107

ANDREOTTI, G.; FREEMAN, L. E.; HOU, L.; COBLE, J.; RUSIECKI, J.; HOPPIN, J. A.; SILVERMAN, D. T.; ALAVANJA, M. C. Agricultural pesticide use and pancreatic cancer risk in the Agricultural Health Study Cohort. International Journal of Cancer, v. 124, p. 2495-2500, 2009. https://doi.org/10.1002/ijc.24185

ANTONUCCI, G. A.; SYLLOS CÓLUS, I. M. Chromosomal aberrations analysis in a Brazilian population exposed to pesticides. Teratogenesis, Carcinogenesis, and Mutagenesis Banner, v. 20, n. 5, p. 265-272, 2000. https://doi.org/10.1002/15206866(2000)20:5\%3C265::AID-TCM2\%3E3.0.CO;2-\%23

ARAÚJO, A. C.; NOGUEIRA, D. P.; AUGUSTO, L. G. Pesticide impact on health: a study of tomato cultivation. Revista de Saúde Pública, v. 34, n. 3, p. 309-313, 2000. https://doi.org/10.1590/S0034-89102000000300016

ARAÚJO, A. J.; LIMA, J. S.; MOREIRA, J. C.; JACOB, S. do C.; SOARES, M. de O.; MONTEIRO, M. C.; AMARAL, A. M.; KUBOTA, A.; MEYER, A.; COSENZA, C. A.; NEVES, C.; MARKOWITZ, S. Multiple exposure to pesticides and impacts on health: a cross-section study of 102 rural workers, Nova Friburgo, Rio de Janeiro State, Brazil. Ciência \& Saúde Coletiva, v. 12 , n. 1, p. 115-130, 2007. http://dx.doi.org/10.1590/S1413-81232007000100015

ARAÚJO-PINTO, M. D.; PERES, F.; MOREIRA, J. C. Using the 'Driving Force - Pressure - State - Exposure - Effects - Action' (DPSEEA) model of the World Health Organization (WHO) for the analysis of risks related to the use of pesticides in agricultural activities in the state of Rio de Janeiro]. Ciência \& Saúde Coletiva, v. 17, n. 6, p. 1543-1555, 2012. http:// dx.doi.org/10.1590/S1413-81232012000600018

ASSOCIAÇÃO NACIONAL DE DEFESA VEGETAL. Manual de segurança e saúde do aplicador de produtos fitossanitários. Campinas: Linea Creativa, 2006.

AUGUSTO, L. G. S.; CARNEIRO, F. F.; PIGNATI, W.; RIGOTTO, R. M.; FRIEDRICH, K.; FARIA, N. M. X.; BÚRIGO, A. C.; FREITAS, V. M. T.; GUIDUCCI FILHO, E. (Orgs.). Dossiê Abrasco: um alerta sobre os impactos dos agrotóxicos na saúde: 2a Parte. Rio de Janeiro: Abrasco, 2012.

BARCELLOS, M.; FALETTI, M. M.; MADUREIRA, L. A.; BAUER, F. C. Analytical evaluation of the protection offered by sealed tractor cabins during crop pulverization with fenitrothion. Environmental Monitoring and Assessment, v. 188, n. 12, p. 660, 2016. https://doi.org/10.1007/s10661-016-5632-5

BAZILIO, M. M.; FROTA, S.; CHRISMAN, J. R.; MEYER, A.; ASMUS, C. I.; CAMARA, V. de M. Temporal auditory processing in rural workers exposed to pesticide. Jornal da Sociedade Brasileira de Fonoaudiologia, v. 24, n. 2, p. 174-180, 2012. http://dx.doi.org/10.1590/S2179-64912012000200015

BEANE FREEMAN, L. E.; BONNER, M. R.; BLAIR, A.; HOPPIN, J. A.; SANDLER, D. P.; LUBIN, J. H.; DOSEMECI, M.; LYNCH, C. F.; KNOTT, C.; ALAVANJA, M. C. R. Cancer incidence among male in the Agricultural Health Study cohort exposed to diazinon. American Journal of Epidemiology, v. 162, n. 11, p. 1070-1079, 2005. https://doi.org/10.1093/aje/kwi321 
BEDOR, C. N.; MORAIS, R. J.; CAVALCANTI, L. S.; FERREIRA, J. V.; PAVÃO, A. C. Carcinogenic potential of endosulfan and its metabolites based on a quantum chemical model. Science of the Total Environment, v. 408, n. 24, p. 6281-6284, 2010. https://doi.org/10.1016/j.scitotenv.2010.09.014

BENEDETTI, D.; NUNES, E.; SARMENTO, M.; PORTO, C.; SANTOS, C. E. I.; DIAS, J. F.; SILVA, J. Genetic damage in soybean workers exposed to pesticides: evaluation with the comet and buccal micronucleus cytome assays. Mutation Research, v. 752, n. 1-2, p. 28-33, 2013. https://doi.org/10.1016/j.mrgentox.2013.01.001

BONNER, M. R.; WILLIAMS, B. A.; RUSIECKI, J. A.; BLAIR, A.; BEANE FREEMAN, L. E.; HOPPIN, J. A.; DOSEMECI, M.; LUBIN, J.; SANDLER, D. P.; ALAVANJA, M. C. Occupational exposure to terbufos and the incidence of cancer in the Agricultural Health Study. Cancer Causes Control, v. 21, n. 6, p. 871-877, 2010. https://doi.org/10.1007/s10552-010-9514-9

BRASIL. Ministério da Agricultura, Pecuária e Abastecimento. Relatório de Gestão 2013. Brasil: Ministério da Agricultura, Pecuária e Abastecimento, 2013. Available at: <http://www.agricultura.gov.br/acesso-a-informacao/auditorias/2013/ sfa-go.pdf>. Acessed on: Oct., 2018.

. Ministério do Meio Ambiente. Segurança Química. Agrotóxicos. Brasil: Ministério do Meio Ambiente, 2015. Available at: <http://www.mma.gov.br/seguranca-quimica/agrotoxicos>. Acessed on: Oct., 2018.

BREGA, S. M.; VASSILIEFF, I.; ALMEIDA, A.; MERCADANTE, A.; BISSACOT, D.; CURY, P. R.; FREIRE-MAIA, D. V. Clinical, cytogenetic and toxicological studies in rural workers exposed to pesticides in Botucatu, São Paulo, Brazil. Cadernos de Saúde Pública, v. 14, supl. 3, p. S117-123, 1998. http://dx.doi.org/10.1590/S0102-311X1998000700011

BREIHL, J. Epidemiología crítica: ciencia emancipadora e interculturalidad. Buenos Aires: Lugar Editorial, 2003.

CALDAS, E. D.; COELHO, R.; SOUZA, L. C. K. R.; SILVA, S. C. Organochlorine Pesticides in Water, Sediment, and Fish of Paranoá Lake of Brasilia, Brazil. Bulletin of Environmental Contamination and Toxicology, v. 62, n. 2, p. 199-206, 1999.

CALDAS, S. S.; ZANELLA, R.; PRIMEL, E. G. Risk Estimate of Water Contamination and Occurrence of Pesticides in the South of Brazil. Herbicides and Environment, p. 471-492, 2011.

CARNeIRO, F. F.; PIGNATI, W.; RIGOtTO, R. M.; AUGUStO, L. G. S.; RIZOlLO, A.; MULleR, N. M.; ALEXANDRE, V. P.; FRIEDRICH, K.; MELLO, M. S. C. (Orgs.). Dossiê Abrasco: um alerta sobre os impactos dos agrotóxicos na saúde: 1a Parte. Rio de Janeiro: Abrasco, 2012.

CARNEIRO, F. F.; TAMBELLINI, A. T.; SILVA, J. A.; HADDAD, J. P. A.; BÚRIGO, A. C.; SÁ, W. R.; VIANA, F. C.; BERTOLINI, V. A. Health of families from the Landless Workers' Movement and temporary rural workers, Brazil, 2005. Revista de Saúde Pública, v. 42, n. 4, p. 757-763, 2008. http://dx.doi.org/10.1590/S0034-89102008005000037

CARVALHO, W. A. Risk factors related with occupational and environmental exposure to organochlorine insecticides in the state of Bahia, Brazil, 1985. Boletín de la Oficina Sanitaria Panamericana, v. 111, n. 6, p. 512-524, 1991.

CAVALHEIRO, C. N.; REMPEL, C.; LAROQUE, L. F. S.; MACHADO, B. N. B. Perfil socioeconômico e análise da qualidade de vida dos produtores de leite da comunidade São Justino, em Juína/MT. Destaques Acadêmicos, v. 6, n. 3, p. 148-156, 2014.

CEZAR-VAZ, M. R.; BONOW, C. A.; MELLO, M. C.; SILVA, M. R. Socio-environmental approach in nursing: focusing on rural labor and the use of pesticides. Revista Brasileira de Enfermagem, v. 69, n. 6, p. 1179-1187, 2016. https:// dx.doi.org/10.1590/0034-7167-2016-0364

CEZAR-VAZ, M. R.; BONOW, C. A.; PIEXAK, D. R.; KOWALCZYK, S.; VAZ, J. C.; BORGES, A. M. Skin cancer in rural workers: nursing knowledge and intervention. Revista da Escola de Enfermagem da USP, v. 49, n. 4, p. 564-571, 2015. https:// dx.doi.org/10.1590/S0080-623420150000400005 
CHAUDHURI, R. N. Occupational health problems among agricultural and plantation workers. Journal of the Indian Medical Association, v. 98, n. 8, p. 439-441, 2000.

CONTI, C. L.; BARBOSA, W. M.; SIMÃO, J. B. P.; ÁLVARES-DA-SILVA, A. M. Pesticide exposure, tobacco use, poor self-perceived health and presence of chronic disease are determinants of depressive symptoms among coffee growers from Southeast Brazil. Psychiatry Research, v. 260, p. 187-192, 2018. https://dx.doi.org/10.1016/j.psychres.2017.11.063

CREMONESE, C.; PICCOLI, C.; PASQUALOTTO, F.; CLAPAUCH, R.; KOIFMAN, R. J.; KOIFMAN, S.; FREIRE, C. Occupational exposure to pesticides, reproductive hormone levels and sperm quality in young Brazilian men. Reproductive Toxicology, v. 67, p. 174-185, 2017. https://doi.org/10.1016/j.reprotox.2017.01.001

DE BRITO SÁ STOPPELLI, I. M.; CRESTANA, S. Pesticide exposure and cancer among rural workers from Bariri, Sao Paulo State, Brazil. Environment International, v. 31, n. 5, p. 731-738, 2005. https://doi.org/10.1016/j.envint.2005.02.002

DOĞANLAR, Z. B.; DOĞANLAR, O.; TOZKIR, H.; GÖKALP, F. D.; DOĞAN, A.; YAMAÇ, F.; AŞKIN, O. O.; AKTAŞ, U. E. Nonoccupational Exposure of Agricultural Area Residents to Pesticides: Pesticide Accumulation and Evaluation of Genotoxicity. Archives of Environmental Contamination and Toxicology, v. 75, n. 4, p. 530-544, 2018. https://doi. org/10.1007/s00244-018-0545-7

ECKERMAN, D. A.; GIMENES, L. S.; DE SOUZA, R. C.; GALVÃO, P. R.; SARCINELLI, P. N.; CHRISMAN, J. R. Age related effects of pesticide exposure on neurobehavioral performance of adolescent farm workers in Brazil. Neurotoxicology and Teratology, v. 29, n. 1, p. 164-175, 2007. https://doi.org/10.1016/j.ntt.2006.09.028

FARIA, N. M.; FACCHINI, L. A.; FASSA, A. G.; TOMASI, E. A cross-sectional study about mental health of farm-workers from Serra Gaucha (Brazil). Revista de Saúde Pública, v. 33, n. 4, p. 391-400, 1999. http://dx.doi.org/10.1590/S0034-89101999000400011

FARIA, N. M.; FACCHINI, L. A.; FASSA, A. G.; TOMASI, E. The rural labor process and health in the Southern Brazilian mountains: a descriptive study. Caderno de Saúde Pública, v. 16, n. 1, p. 115-128, 2000. http://dx.doi.org/10.1590/ S0102-311X2000000100012

FARIA, N. M.; FASSA, A. G.; MEUCCI, R. D. Association between pesticide exposure and suicide rates in Brazil. Neurotoxicology, v. 45, p. 355-362, 2014a. https://doi.org/10.1016/j.neuro.2014.05.003

FARIA, N. M.; FACCHINI, L. A.; FASSA, a.g.; TOMASI, E. Trabalho rural e intoxicações por agrotóxicos. Cad. Saúde Pública, v.20, n. 5, p.1298-1308, 2004.

FARIA, N. M.; FASSA, A. G.; MEUCCI, R. D.; FIORI, N. S.; MIRANDA, V. I. Occupational exposure to pesticides, nicotine and minor psychiatric disorders among tobacco farmers in southern Brazil. Neurotoxicology, v. 45, p. 347-354, $2014 \mathrm{~b}$. https://doi.org/10.1016/j.neuro.2014.05.002

FERRAZ, H. B.; BERTOLUCCI, P. H.; PEREIRA, J. S.; LIMA, J. G.; ANDRADE, L. A. Chronic exposure to the fungicide maneb may produce symptoms and signs of CNS manganese intoxication. Neurology, v. 38, n. 4, p. 550-553, 1988.

FIORI, N. S.; FASSA, A. G.; FARIA, N. M.; MEUCCI, R. D.; MIRANDA, V. I.; CHRISTIANI, D. C. Wheezing in tobacco farm workers in southern Brazil. American Journal of Industrial Medicine, v. 58, n. 11, p. 1217-1228, 2015. http://dx.doi. org/10.1002/ajim.22447

FREIRE, C.; KOIFMAN, R. J.; SARCINELLI, P. N.; ROSA, A. C.; CLAPAUCH, R.; KOIFMAN, S. Association between serum levels of organochlorine pesticides and sex hormones in adults living in a heavily contaminated area in Brazil. International Journal of Hygiene Environmental Health, v. 217, p. 2-3, p. 370-378, 2014. https://doi.org/10.1016/j.ijheh.2013.07.012

GODOY, F. R.; COSTA, E. O.; DA SILVA REIS, A. A.; BATISTA, M. P.; MELO, A. V.; GONÇALVES, M. W.; CRUZ, A. S.; MELO, C. O. A.; MINASI, L. B.; RIBEIRO, C. L.; CRUZ, A. D.; SILVA, D. M. Do GSTT1 and GSTM1 polymorphisms influence intoxication events in individuals occupationally exposed to pesticides? Environmental Science and Pollution Research International, v. 21, n. 5, p. 3706-3712, 2014. https://doi.org/10.1007/s11356-013-2349-7 
GONÇALVES, M. S. Uso sustentável de pesticidas. Análise comparativa entre a União Europeia e o Brasil. Tese (Doutorado) - Departamento de Biologia Vegetal, Faculdade de Ciências, Universidade de Lisboa, Lisboa, 2016.

GRISOLIA, C. K. Agrotóxicos: mutações, câncer \& reprodução. Brasília: UnB, 2005.

HERNÁNDEZ, A. F.; PARRÓN, T.; TSATSAKIS, T.; REQUENA, M.; ALARCÓN, R.; LÓPEZ-GUARNIDO, O. Toxic effects of pesticide mixtures at a molecular level: their relevance to human health. Toxicology, v. 307, p. 136-145, 2013. https:// doi.org/10.1016/j.tox.2012.06.009

HILGERT JACOBSEN-PEREIRA, C.; DOS SANTOS, C. R.; TROINA MARASLIS, F.; PIMENTEL, L.; FEIJÓ, A. J. L.; IOMARA SILVA, C.; DE MEDEIROS, G. D. S.; COSTA ZEFERINO, R.; CURI PEDROSA, R.; WEIDNER MALUF, S. Markers of genotoxicity and oxidative stress in farmers exposed to pesticides. Ecotoxicology and Environmental Safety, v. 148, p. 177-183, 2018. https://doi.org/10.1016/j.ecoenv.2017.10.004

INSTITUTO BRASILEIRO DE GEOGRAFIA E ESTATÍSTICA (IBGE). Censo agropecuário de 2006: resultados preliminares. IBGE, 2006. Available at: <www.ibge.gob.br>. Acessed on: Oct., 2009.

INSTITUTO BRASILEIRO DO MEIO AMBIENTE E DOS RECURSOS NATURAIS RENOVÁVEIS (IBAMA). Consolidação de dados fornecidos pelas empresas registrantes de produtos técnicos, agrotóxicos e afins, conforme art. 41 do Decreto $n$ o 4.074/2002. Disponível em: <http://ibama.gov.br/component/phocadownload/category/21-agrotoxicos>. Accessed on: Dec. 7, 2018.

IWAMI, A.; FERREIRA, C. P.; DINNOUTI, L. A.; BUENO, F.; ARAÚJO, R. M.; GONSALVES, T.; SANTIAGO, T. Manual de uso correto e seguro de produtos fitossanitários. São Paulo: Linea Creativa, 2010.

JACOBSON, L. S. V.; HACON, S. S.; ALVARENGA, L.; GOLDSTEIN, R. A.; GUMS, C.; BUSS, D. F.; LEDA, L. R. Comunidade pomperana e uso de agrotóxicos: uma realidade pouco conhecida. Ciência \& Saúde Coletiva, v. 14, n. 6, p. 2239-2249, 2009. http://dx.doi.org/10.1590/S1413-81232009000600033

KHAYAT, C. B.; COSTA, E. O.; GONÇALVES, M. W.; DA CRUZ E CUNHA, D. M.; DA CRUZ, A. S.; DE ARAÚJO MELO, C. O.; BASTOS, R. P.; DA CRUZ, A. D.; DE MELO E SILVA, D. Assessment of DNA damage in Brazilian workers occupationally exposed to pesticides: a study from Central Brazil. Environmental Science and Pollution Research International, v. 20, n. 10, p. 7334-7340, 2013. https://doi.org/10.1007/s11356-013-1747-1

LAABS, V.; AMELUNG, W.; PINTO, A. A.; WANTZEN, M.; DA SILVA, C. J.; ZECH, W. Pesticides in Surface Water, Sediment, and Rainfall of the Northeastern Pantanal Basin, Brazil. Journal of Environmental Quality Abstract - Organic Compounds in the Environment, v. 31, n. 5, p. 1636-1648, 2002. https://doi.org/10.2134/jeq2002.1636

LAABS, V.; AMELUNG, W.; PINTO, A.; ZECH, W. Fate of pesticides in tropical soils of Brazil under field conditions. Journal of Environmental Quality, v. 31, n. 1, p. 256-268, 2002. http://dx.doi.org/10.2134/jeq2002.0256

LEVIGARD, Y. E.; ROZEMBERG, B. A interpretação dos profissionais de saúde acerca das queixas de "nervos" no meio rural: uma aproximação ao problema das intoxicações por agrotóxicos. Cadernos de Saúde Pública, v. 20, n. 6, p. 1515-1524, 2004. http://dx.doi.org/10.1590/S0102-311X2004000600008

LEVIGARD, Y. E.; ROZEMBERG, B. A Interpretação dos Profissionais de Saúde acerca do Nervoso no Meio Rural. Dissertação (Mestrado) - Centro de Estudos da Saúde do Trabalhador e Ecologia Humana, Escola Nacional de Saúde Pública, Fundação Oswaldo Cruz, Rio de Janeiro, 2001.

MARONI, M.; FAIT, A.; COLOSIO, C. Risk assessment and management of occupational exposure to pesticides. Toxicology Letters, v. 107, n. 1-3, p. 145-153, 1999. https://doi.org/10.1016/S0378-4274(99)00041-7

MEYER, A.; CHRISMAN, J.; MOREIRA, J. C.; KOIFMAN, S. Cancer mortality among agricultural workers from Serrana Region, state of Rio de Janeiro, Brazil. Environmental Research, v. 93, n. 3, p. 264-271, 2003. 
MEYER, A.; KOIFMAN, S.; KOIFMAN, R. J.; MOREIRA, J. C.; DE REZENDE CHRISMAN, J.; ABREU-VILLACA, Y. Mood disorders hospitalizations, suicide attempts, and suicide mortality among agricultural workers and residents in an area with intensive use of pesticides in Brazil. Journal of Toxicology Environmental Health A, v. 73, n. 13-14, p. 866-877, 2010. https://doi.org/10.1080/15287391003744781

MIRANDA, A. C.; MOREIRA, J. C.; CARVALHO, R.; PERES, F. Neoliberalismo, uso de agrotóxicos e a crise da soberania alimentar no Brasil. Ciência \& Saúde Coletiva, v. 12, n. 1, p. 7-14, 2007. http://dx.doi.org/10.1590/S141381232007000100002

MIRANDA FILHO, A. L.; KOIFMAN, R. J.; KOIFMAN, S.; MONTEIRO, G. T. Brain cancer mortality in an agricultural and a metropolitan region of Rio de Janeiro, Brazil: a population-based, age-period-cohort study, 1996-2010. BMC Cancer, v. 14, p. 320, 2014. https://doi.org/10.1186/1471-2407-14-320

MURUSSI, C.; HORN, R. C.; SANTI, A.; CLASEN, B. E.; REIS, G.; SOUZA, D.; BORTOLOTTO, J. W.; MANFIO, C. E.; LORO, V. L. Changes in oxidative markers, endogenous antioxidants and activity of the enzyme acetylcholinesterase in farmers exposed to agricultural pesticides - a pilot study. Ciência Rural, Santa Maria, v. 44, n. 7, 2014. http://dx.doi. org/10.1590/0103-8478cr20130516

NASRALA NETO, E.; LACAZ, F. A.; PIGNATI, W. A. Health surveillance and agribusiness: the impact of pesticides on health and the environment. Danger ahead! Ciência \& Saúde Coletiva, v. 19, n. 12, p. 4709-4718, 2014. http://dx.doi. org/10.1590/1413-812320141912.03172013

NEVES, F. R. M. Efeito dos agrotóxicos e seus metabólitos em células sanguíneas. Dissertação (Mestrado) - Faculdade de Medicina de Ribeirão Preto, Universidade de São Paulo, Ribeirão Preto, 2017.

OBE, G.; PFEIFFER, P.; SAVAGE, J. R.; JOHANNES, C.; GOEDECKE, W.; JEPPESEN, P.; NATARAJAN, A. T.; MARTÍNEZ-LÓPEZ, W.; FOLLE, G. A.; DRETS, M. E. Chromosomal Aberrations: Formation, Identification and Distribution. Mutation Research, v. 504, n. 1-2, p. 17-36, 2002.

OLIVEIRA-SILVA, J. J.; ALVES, S. R.; MEYER, A.; PEREZ, F.; SARCINELLI, P. N.; DA COSTA MATTOS, R. C.; MOREIRA, J. C. Influence of socioeconomic factors on the pesticides poisoning, Brazil. Revista de Saúde Pública, v. 35, n. 2, p. 130-135, 2001. http://dx.doi.org/10.1590/S0034-89102001000200005

PADEL, S.; RÖCKLINSBERG, H.; SCHMID, O. The implementation of organic principles and values in the European Regulation for organic food. Food Policy, v. 34, p. 245-251, 2009. http://dx.doi.org/10.1016/j.foodpol.2009.03.008

PAIVA, J. C.; CABRAL, I. O.; SOARES, B. M.; SOMBRA, C. M.; FERREIRA, J. R. O.; MORAES, M. O.; CAVALCANTI, B. C.; PESSOA, C. Biomonitoring of rural workers exposed to a complex mixture of pesticides in the municipalities of Tianguá and Ubajara (Ceará state, Brazil): genotoxic and cytogenetic studies. Environmental and Molecular Mutagenesis, v. 52, n. 6, p. 492-501, 2011. http://dx.doi.org/10.1002/em.20647

PASIANI, J. O.; TORRES, P.; RONIERY SILVA, J.; DINIZ, B. Z.; DUTRA CALDAS, E. Knowledge, attitudes, practices and biomonitoring of farmers and residents exposed to pesticides in Brazil. International Journal of Environmental Research and Public Health, v. 9, n. 9, p. 3051-3068, 2012. http://dx.doi.org/10.3390/ijerph9093051

PAUMgaRTTEN, F. J.; DELGADO, I. F.; OliVEIRA, E. S.; ALLELUIA, I. B.; BARRETTO, H. H.; KUSSUMI, T. A. Levels of organochlorine pesticides in the blood serum of agricultural workers from Rio de Janeiro, Brazil. Cadernos de Saúde Pública, v. 14, supl. 3, p. S33-S39, 1998. http://dx.doi.org/10.1590/S0102-311X1998000700005

PEDLOWSKIA, M. A.; CANELAB, M. C.; TERRA, M. A. C.; FARIA, R. M. R. Modes of pesticides utilization by Brazilian smallholders and their implications for human health and the environment. Crop Protection, v. 31, n. 1, p. 113-118, 2012. http://dx.doi.org/10.1016/j.cropro.2011.10.002 
PELAEZ, V.; TERRA, F. B.; SILVA, L. R. A regulamentação dos agrotóxicos no Brasil: entre o poder de mercado e a defesa da saúde e do meio ambiente. Revista de Economia, v. 36, n. 1, p. 27-48, 2010. http://dx.doi.org/10.5380/re.v36i1.20523

PERES, F. É veneno ou é remédio? Os desafios da comunicação rural sobre agrotóxicos. Dissertação (Mestrado) - Escola Nacional de Saúde Pública, Fundação Oswaldo Cruz, Rio de Janeiro, 1999.

PERES, F.; MOREIRA, J. C. Health, environment, and pesticide use in a farming area in Rio de Janeiro State, Brazil]. Cadernos de Saúde Pública, v. 23, supl. 4, p. S612-S621, 2007. http://dx.doi.org/10.1590/S0102-311X2007001600021

PERES, F.; MOREIRA, J. C.; RODRIGUES, K. M.; CLAUDIO, L. Risk perception and communication regarding pesticide use in rural work: a case study in Rio de Janeiro State, Brazil. International Journal of Occupational and Environmental Health, v. 12, n. 4, p. 400-407, 2006. https://doi.org/10.1179/oeh.2006.12.4.400

PERES, F.; RODRIGUES, K. M.; DA SILVA PEIXOTO BELO, M. S.; MOREIRA, J. C.; CLAUDIO, L. Design of risk communication strategies based on risk perception among farmers exposed to pesticides in Rio de Janeiro State, Brazil. American Journal of Industrial Medicine, v. 56, n. 1, p. 77-89, 2013. http://dx.doi.org/10.1002/ajim.22147

PERES, F.; ROZEMBERG, B.; ALVES, S. R.; MOREIRA, J. C.; OLIVEIRA-SILVA, J. J. Communication related to pesticides use in a rural area of the state of Rio de Janeiro, Brazil]. Revista de Saúde Pública, v. 35, n. 6, p. 564-570, 2001. http://dx.doi. org/10.1590/S0034-89102001000600010

PERES, F.; ROZEMBERG, B.; DE LUCCA, S. R. Risk perception related to work in a rural community of Rio de Janeiro State, Brazil: pesticides, health, and environment]. Cadernos de Saúde Pública, v. 21, n. 6, p. 1836-1844, 2005. http://dx.doi. org/10.1590/S0102-311X2005000600033

PIRES, D. X.; CALDAS, E. D.; RECENA, M. C. Pesticide poisoning in Dourados, Mato Grosso do Sul State, Brazil, $1992 / 2002$. Cadernos de Saúde Pública, n. 21, v. 3, p. 804-814, 2005. http://dx.doi.org/10.1590/S0102-311X2005000300014

PORTO, M. F.; SOARES, W. L. Modelo de desenvolvimento, agrotóxicos e saúde: um panorama da realidade agrícola brasileira e propostas para uma agenda de pesquisa inovadora. Revista Brasileira de Saúde Ocupacional, v. 37, n. 125, p. 17-30, 2012. http://dx.doi.org/10.1590/S0303-76572012000100004

RATHORE, M.; BHATNAGAR, P.; MATHUR, D.; SAXENA, G. N. Burden of organochlorine pesticides in blood and its effect on thyroid hormones in women. The Science of the Total Environment, v. 295, n. 1-3, p. 207-2015, 2002.

RECENA, M. C.; CALDAS, E. D.; PIRES, D. X.; PONTES, E. R. Pesticides exposure in Culturama, Brazil--knowledge, attitudes, and practices. Environmental Research, v. 102, n. 2, p. 230-236, 2006. https://doi.org/10.1016/j.envres.2006.01.007

REFFSTRUP, T. K.; LARSEN, J. C.; MEYER, O. Risk assessment of mixtures of pesticides. current approaches and future strategies. Regulatory Toxicology and Pharmacology, v. 56, n. 2, p. 174-192, 2010. https://doi.org/10.1016/j. yrtph.2009.09.013

REMPEL, C.; HAETINGER, C.; SEHNEM, E. Reflexões de idosos sobre as relações entre o trabalho rural, problemas de coluna e postura corporal. Estudos Sociedade e Agricultura, v. 21, n. 2, p. 289-307, 2013.

RIBEIRO, L. R.; SALVADORI, D. M. F.; MARQUES, E. K. Mutagênese Ambiental. Canoas: ULBRA, 2003.

RIGOTTO, R. M.; CARNEIRO, F. F.; MARINHO, A. M. C. P.; ROCHA, M. M.; FERREIRA, M. J. M.; PESSOA, V. M.; TEIXEIRA, A. C. A.; SILVA, M. L. V.; BRAGA, L. Q. V.; TEIXEIRA, M. M. O verde da economia no campo: desafios à pesquisa e às políticas públicas para a promoção da saúde no avanço da modernização agrícola. Ciência \& Saúde Coletiva, v. 17, n. 6, p. 1533-1542, 2012. http://dx.doi.org/10.1590/S1413-81232012000600017 
RISSATO, S. R.; GALHIANE, M. S.; DE ALMEIDA, M. V.; GERENUTTI, M.; APON, B. M. Multiresidue determination of pesticides in honey samples by gas chromatography-mass spectrometry and application in environmental contamination. Analytical, Nutritional and Clinical Methods, v. 101, p. 1719-1726, 2007. https://doi.org/10.1016/j. foodchem.2005.10.034

SENA, T. R. R.; DOURADO, S. S. F.; LIMA, L. V; ANTONIOLLI, Â. R. The hearing of rural workers exposed to noise and pesticides. Noise Health, v. 20, n. 92, p. 23-26, 2018. https://dx.doi.org/10.4103\%2Fnah.NAH_70_16

SENA, T. R. R.; VARGAS, M. M.; OLIVEIRA, C. C. Hearing care and quality of life among workers exposed to pesticides. Ciência \& Saúde Coletiva, v. 18, n. 6, p. 1753-1761, 2013. http://dx.doi.org/10.1590/S1413-81232013000600026

SILVA, E. J. Avaliação dos Efeitos Genotóxicos de Agrotóxicos: Risco Ocupacional e Alimentar. Dissertação (Mestrado em Saúde Humana e Meio Ambiente) - Universidade Federal de Pernambuco, Vitória, 2012.

SILVA, J.; MORAES, C. R.; HEUSER, V. D.; ANDRADE, V. M.; SILVA, F. R.; KVITKO, K.; EMMEL, V.; ROHR, P.; BORDIN, D. L.; ANDREAZZA, A. C.; SALVADOR, M.; HENRIQUES, J. A.; ERDTMANN, B. Evaluation of genetic damage in a Brazilian population occupationally exposed to pesticides and its correlation with polymorphisms in metabolizing genes. Mutagenesis, v. 23, n. 5, p. 415-422, 2008. https://doi.org/10.1093/mutage/gen031

SILVÉRIO, A. C. P.; MACHADO, S. C.; AZEVEDO, L.; NOGUEIRA, D. A.; DE CASTRO GRACIANO, M. M.; SIMÕES, J. S.; VIANA, A. L. M.; MARTINS, I. Assessment of exposure to pesticides in rural workers in southern of Minas Gerais, Brazil. Environmental Toxicology and Pharmacology, n. 55, p. 99-106, 2017. https://dx.doi.org/10.1016/j.etap.2017.08.013

SMITH, A. G.; GANGOLLI, S. D. Organochlorine chemicals in seafood: occurrence and health concerns. Food and Chemical Toxicology, v. 40, n. 6, p. 767-779, 2002.

SOARES, W. L. Uso dos agrotóxicos e seus impactos à saúde e ao ambiente: uma avaliação integrada entre a economia, a saúde pública, a ecologia e a agricultura. Tese (Doutorado em Ciências) - Fundação Oswaldo Cruz, Rio de Janeiro, 2010.

SOARES, W.; ALMEIDA, R. M.; MORO, S. Rural work and risk factors associated with pesticide use in Minas Gerais, Brazil. Cadernos de Saúde Pública, v. 19, n. 4, p. 1117-1127, 2003. http://dx.doi.org/10.1590/S0102-311X2003000400033

SOARES, W.; MORO, S.; ALMEIDA, R. M. Rural workers' health and productivity: an economic assessment of pesticide use in Minas Gerais, Brazil. Applied Health Economics and Health Policy, v. 1, n. 3, p. 157-164, 2002.

SOARES, W. L.; PORTO, M. F. Pesticide use and economic impacts on health. Revista de Saúde Pública, v. 46, n. 2, p. 209-217, 2012. http://dx.doi.org/10.1590/S0034-89102012005000006

SOUZA, A. de; MEDEIROS, A. R.; SOUZA, A. C.; WINK, M.; SIQUEIRA, I. R.; FERREIRA, M. B. C.; FERNANDES, L.; HIDALGO, M. P. L.; TORRES, I. L. S. Avaliação do impacto da exposição a agrotóxicos sobre a saúde de população rural: Vale do Taquari (RS, Brasil). Ciência e Saúde Coletiva, v. 16, n. 8, p. 3519-3528, 2011. http://dx.doi.org/10.1590/S141381232011000900020

STÉDILE,J P. Brasil nonecesita venenospara sostener producción alimentaria.Agronotícias América LatinayElCaribe, 2012. Disponível em: <http://www.fao.org/agronoticias/agrot-ticias/detalle/es/?dyna_fef\%5bbackuri\%5d=agronoticias/ archivo/mensual/es/?mes=2011>. Acessed on: July 7, 2014.

STOPPELLI, I. M. de B. S.; MAGALHÃES, C. P. Saúde e segurança alimentar: a questão dos agrotóxicos. Ciência \& Saúde Coletiva, v. 10, Supl., p. S91-S100, 2005. http://dx.doi.org/10.1590/S1413-81232005000500012

TOMIAZZI, J. S.; JUDAI, M. A.; NAI, G. A.; PEREIRA, D. R.; ANTUNES, P. A.; FAVARETO, A. P. A. Evaluation of genotoxic effects in Brazilian agricultural workers exposed to pesticides and cigarette smoke using machine-learning algorithms. Environmental Science and Pollution Research, v. 25, n. 2, p. 1259-1269, 2018. https://doi.org/10.1007/s11356-017-0496-y 
VIEL, J. F.; CHALLIER, B. Bladder cancer among French farmers: does exposure to pesticides in vineyards play a part? Occupational and Environmental Medicine, v. 52, n. 9, p. 587-592, 1995.

WAHLBRINCK, M. G.; BICA, J. B.; REMPEL, C. Percepção dos agricultores do município de Imigrante (RS) sobre o risco da exposição de agrotóxicos. Revista Brasileira de Ciências Ambientais, v. 44, p. 72-84, 2017. https://doi.org/10.5327/ Z2176-947820170128

WILSON, J. S.; OTSUKI, T. To spray or not to spray: pesticides, banana exports, and food safety. Food Policy, v. 29, n. 2, p. 131-146, 2004. https://doi.org/10.1016/j.foodpol.2004.02.003

WORLD HEALTH ORGANIZATION (WHO). Principles and Methods for the Risk Assessment of Chemicals in Food. Maximum Residue Limits for Pesticides and Veterinary Drugs. Genebra: WHO, 2008. Available at: <http://www.who. int/foodsafety/chem/residue_limits.pdf>. Acessed on: Dec. 7, 2018. 